\title{
The Enforcement of Election Criminal Law in Indonesia
}

\author{
Diding Rahmat ${ }^{1}$, Junaedi $^{2}$ \\ \{didingrahmat@uniku.ac.id ${ }^{1}$ \} \\ Law Faculty of Universitas Kuningan, Kuningan, Indonesia ${ }^{1}$ \\ Law Faculty of Universitas Swadaya Gunung Jati, Cirebon, Indonesia ${ }^{2}$
}

\begin{abstract}
The purpose of this study was to determine the regulation of election criminal acts in Indonesia and how to enforce the law. Election crime regulations are regulated in Law Number 7 of 2017 Concerning Elections, namely Article 488 through Article 554. Election criminal law enforcement in Indonesia there are 116 cases consisting of 29 cases of money politics, 22 cases of acts harming election participants, 15 cases counterfeiting, 10 cases of campaigning in places of worship or educational institutions, 9 cases of campaigning outside the schedule, 17 cases of campaigning involving banned parties, 7 cases of campaigning using government facilities, 5 cases of destruction of props and 2 cases concerning the election of participants and their data still, then, in general, the implementation has run well even though at the level of implementation there are only weaknesses such as the substance of the regulation and sanctions for election crimes are multiple interpretations along with severe sanctions, from the structure in this case there are still law enforcement officers in this case GAKUMDU, Bawaslu, and the police. The weaknesses experienced by weaknesses such as in terms of budget, human resources and facilities and infrastructure aside from the side, culture namely the culture of the community which is still low in the awareness of elections in Indonesia, makes violations of election criminal offenses still high.
\end{abstract}

Keywords: Law enforcement, Criminal acts, General elections

\section{Introduction}

The Indonesian state adheres to the principle of "dynamic legal state" or Welfare State as stated in Article 1 paragraph (3) of the 1945 Constitution of the Republic of Indonesia which formulates "The Indonesian State is the State of Law". The rule of law is the basis for a country in carrying out actions that place the principle of legality as the basis for the actions of a country.

Elections are a medium for power change in the democratic climate of Pancasila in Indonesia. In addition to the General Election (PEMILU), there is also a Regional Head Election (PILKADA), between elections and elections to regions based on existing regulations in Indonesia carried out simultaneously by the schedule set by the General Election Commission. Elections have an important meaning in a democratic country, because they relate to three main functions, namely (1) Political legitimacy, through elections, the legitimacy of the government or the ruler is confirmed because the elected government is essentially the choice of the majority of people who have sovereignty. (2) Circulation of the political elite. With elections, the circulation or replacement of the power elite is carried out more equitably, because it is the citizens who directly determine who is still considered qualified as a political elite and who is 
not. (3) Political education. Elections function as a tool to conduct political education for citizens to understand their political rights and obligations. With involvement in the election implementation process, it is hoped that citizens will get direct lessons about how citizens should take part in the democratic system [1].

The General Election is a means of implementing people's sovereignty in the United State of the Republic of Indonesia based on the Pancasila and the 1945 Constitution of the Republic of Indonesia. The holding of the General Election aims to elect the people's representatives and regional representatives and to form a democratic, strong government and gain popular support to realize the national goals as the 1945 Constitution of the Republic of Indonesia. The application of democratic principles in the context of realizing people's sovereignty is expected to be a motivation in the implementation of general elections, and most importantly, to increase people's political awareness to participate actively in general elections for the realization of the ideals of a democratic Indonesian society [2].

The legal basis for general elections in the constitution is Article $22 \mathrm{E}$ of the 1945 Constitution. Whereas elections to regions are regulated in Article 18 paragraphs (3) and (4). Election trips and regional head elections in Indonesian history began from 1955 until now.

The principle of elections is based on the mandate of the constitution and laws and regulations, namely direct, general, free, confidential, honest and fair. To maintain this principle, various rules in the process of general elections and regional head elections have been made, one of which is that governs the criminal acts of general elections and regional head elections.

There are still many violations of general election crimes, making the election process must be reviewed so that the process is by the principles and objectives of the election. Law enforcement in the criminal act of elections in Indonesia in material and formal terms must emphasize the principles, principles, and values of electoral in Indonesia.

\section{Method}

The method used in this study was a normative juridical method. This method was used to analyze secondary data related to the problem under study by applying library research. The collected data were then analyzed qualitatively.

\section{Results and Discussion}

\subsection{The regulation of election criminal in Indonesia}

The legal basis for general elections in Indonesia is regulated in Article $22 \mathrm{E}$ of the 1945 Constitution paragraph (1) to paragraph (6), namely: (1). Elections are held in a direct, general, free, confidential, honest and fair manner every five years. (2). Elections are held to elect members of the People's Legislative Assembly, the Regional Representative Council, the President, and vice-president and the Regional People's Representative Council. (3). Participants in the general election to elect members of the People's Legislative Assembly and members of the Regional People's Legislative Assembly are political parties. (4). Participants in the general election to elect members of the Regional Representative Council are individuals. 
(5). General elections are held by a national, permanent and independent election commission.

(6). Further provisions regarding general elections are regulated by law.

The legal basis for operational elections in 2019 is Law No. 7 of 2017 concerning General Elections. In the provisions of the regulation, there are 77 election criminal offenses regulated in 66 Article criminal provisions, namely from Article 488 to Article 544. While the legal basis for the election of regional heads is contained in Law number 10 of 2016 concerning the Second Amendment to Law Number 1 of 2015 Concerning the Establishment of Government Regulation instead of Law Number 1 of 2014 Regarding the Election of Governors, Regents and Mayors Become Laws.

Crimes in the electoral field, in addition to being regulated in the Election Law, are also regulated in the Criminal Code and other laws and regulations. Although in the Criminal Code and other laws and regulations do not explicitly declare such acts as an election crime. Some provisions relating to criminal offenses in the electoral field which are explicitly regulated in the Criminal Code are contained in Chapter IV with the title Crimes Against Conducting Obligations and State Rights, Articles 146 through 153. There are also Article provisions that are not directly related to the Election but the qualifications of their actions are threatened in the Criminal Code. In this case, for example, the requirements of candidates for Regional Heads / Deputy Regional Heads are falsified so that they meet the administrative requirements to participate in the pair of candidates to be elected. If this happens, the qualifications for the action are included in the formulation of Article 263 of the Criminal Code concerning the falsification of the letter. Law enforcement against criminal offenses in the field of Elections outside the Criminal Code is carried out concerning the Criminal Procedure Code. So that the procedure for the same procedure with the procedure for other general criminal acts. Whereas the criminal act of Pemilukada is a crime that occurs during the stages of the holding of the Election of Regional Head / Deputy Regional Head, namely starting voter registration, campaign period, voting, vote counting, etc. [3].

In the 2019 general election based on general election rules. There are several kinds of subjects (perpetrators) of election crimes namely, each person (as many as 22 criminal acts out of 77 election criminal acts). This is commonly called communal offense (a crime that can be done by anyone). And the rest, as many as 55 criminal acts constitute the offense of Prophecies (criminal acts with certain subjects / not everyone), in Law No. 7 of 2017 the subjects vary, namely the organizers of the General Elections starting from the lowest (Voting Organizer Group) to the highest (General Election Commissions). There are 23 election criminal offenses out of 77 election criminal offenses, or around 18 percent of all election criminal offenses the subjects are election organizers from the Chairperson of the KPU to the KPPS. Election Supervisors from the lowest to the highest are subject to criminal acts in 3 (three) Election criminal acts. While the election campaign organizers, election campaign participants, election participants, presidential and vice-presidential candidates and leaders of political parties are the subjects of 13 election criminal offenses. This means that more criminal acts are threatened by election organizers compared to campaign organizers, campaign participants, election participants, candidates for President and Vice President, and leaders of political parties [4].

The many types of election law problems are also linear with the large number of institutions involved in handling it. There are at least nine institutions involved namely: (1) Election Organizer Honorary Council (DKPP), (2) Supervisory Board Election (Bawaslu); (3) General Election Commission (KPU); (4) National Police; (5) Attorney; (6) State Administrative Court and Administrative High Court Country; (7) District Courts and High Courts; (8) Supreme Court; and (9) Constitutional Court. Not to mention the involvement of the Broadcasting Commission or the Council Press to oversee the reporting and advertising of 
campaigns. So, at the very least there will be 10 institutions related to the resolution of election law problems. The many types of problems and the many parties involved show so complex is the electoral legal problem, or at least a legal problem election is designed so complex. Let alone to carry out, understanding it also requires extra energy so that no misunderstanding will result fatal in its implementation. In turn, law enforcement election crimes also face various problems, both because of the content of the rules which is not too supportive or due to law enforcement and cultural factors [5].

Criminal election in Indonesia in its development through many changes in the form of an increase in criminal until differences on the addition of criminal sanctions. This is because the more the criminal election increasingly become increasingly serious concern because the measure of success of the democratic state held his views on the success of the election. The government then tighten the law on elections to further aggravate criminal sanctions for perpetrators of criminal election. Furthermore, with the hope and that with the Act No. 7 of 2017 as Law. The latest law on election of members of DPR, DPD and DPRD as the rules of elections that have been refined from the previous Law. This Act has been anticipating the event of a crime and affirmed that there are 4 (four) institutions involved in handling the criminal case elections Supervisory Committee Election (Bawaslu), police, prosecutors, and courts. It can be said that criminal election is seen as something forbidden act of serious nature and should be completed within 7 shorts, in order to achieve the purpose of organized criminal provisions to protect the democratic process through elections. As stipulated by the reforms, that the holding of elections for the future must be made and implemented in a better quality. In the elections despite the law. Law and special regulations concerning the elections in order to run properly, but there are still some violations and fraud. Violations and fraud were done by the organizers of the election, the election participants even by the people themselves.

Authority Election dispute resolution which is divided into many institutions is also demanding simplification is done. That fact wants it to do reconstruction related to the resolution of all types of election legal issues, including election results dispute. Related to that, one of the proposals offered through This paper is the simplification of a settlement system and a judicial institution involved in dispute resolution. Where, for dispute resolution the election results remain the authority of the Constitutional Court, while the dispute resolution elections, local election disputes and local election outcome disputes are handled by special courts election. The role of the intended election court will be carried out by Bawaslu which will transform into a special election court [6].

\subsection{Election Crime Law Enforcement in Indonesia}

Law enforcement of election criminal acts in Indonesia is based on a separate procedural law system, namely in the investigation process carried out by the Election Supervisory Body, then in the investigation carried out by the police, prosecution is carried out by the public prosecutor and the examination is carried out by a judge in the district court and the high court on appeal.

Elections are a tangible form of the concept of democracy which is believed to be one of the principles of governance in Indonesia. But in the implementation of the democratic party on its way there are still deficiencies. Some things that are often highlighted are the rise of money politics in every leadership election in this country, ranging from village head elections to presidential elections may have become roots that are not easy to dry. One factor contributing to the rise of money politics is the lack of awareness among the majority of the Indonesian people that elections are the most effective vehicle for upholding people's sovereignty. As an 
example, the existence of fictitious or fake voices often colors the party of democracy in this country. The public is less aware that the various incidents that had arisen earlier could be categorized as election crimes that had a strict sanction threat. Law No. 7 of 2017 concerning Elections shows the seriousness of the government in eradicating election crime through the formation of Gakkumdu. Gakkumdu as an integrated law enforcement center has an important role in handling election criminal acts. In Article 486 point (1) of Law No. 7 of 2017 explicitly explained the establishment of Gakkumdu intends to equalize the understanding and pattern of handling election criminal acts by the Bawaslu, the Indonesian National Police, and the Attorney General's Office of the Republic of Indonesia. The Gakkumdu members themselves come from the Indonesian National Police and prosecutors from the Attorney General's Office of the Republic of Indonesia. The topic of the issue that will be discussed in this article is the role of Gakkumdu in suppressing election criminal acts in the 2019 general elections [7].

Election criminal law enforcement mechanisms must meet the principles of democracy, so each judge's decision must always meet at least 3 (three) important perspectives including the perspective of material criminal law, the perspective of formal criminal law and the perspective of criminal conduct. First, the material criminal perspective contains behavior that is threatened with a crime, who can be convicted and various kinds of criminal sentences. In other words, material criminal law contains norms and penal sanctions as well as general provisions that limit, expand or explain the norms and penalties. Second, a formal criminal perspective (adjective criminal law) or commonly referred to as criminal procedural law, which can be interpreted in all regulations which contain the ways of the State in using its right to implement criminal law enforcement which has implications for the application of sanctions for material criminal offenders. Third, the perspective of criminal conduct or punishment cannot be separated from the criminal justice system. Article 270 of the Criminal Procedure Code stipulates that the Prosecutor carries out a court decision. How prosecutors carry out these decisions is regulated in the KUHAP implementation rules or other words, prosecutors who are not public prosecutors for a case may carry out a court decision [8].

There are 116 cases of criminal law enforcement in Indonesia, consisting of 29 cases of money politics, 22 cases of acts harming election participants, 15 cases of forgery, 10 cases of campaigning in places of worship or educational institutions, 9 cases of campaigns outside the schedule, 17 cases of campaigns involving parties which is prohibited, 7 cases of campaigns using government facilities, 5 cases of destruction of props and 2 cases concerning the election of participants and the election data.

Based on the data above, it can be concluded that there are still many criminal acts in the general election which are related to the legal system theory firstly, from the structural point of view, the role of integrated law enforcement (GAKUMDU) in which there are Bawaslu, police, and prosecutors have not been maximal in disseminating information about election criminal acts to public or participants of the election, besides that the human resources are still low, lack of budget and lack of facilities and infrastructure. Second, in terms of culture, namely the legal culture of the community regarding election crimes is still low and the culture of money politics is still rife.

The position of the Election Supervisory Board in the Indonesian administration system is one of the state election organizers in which its position is equal to the General Election Commission and the Honorary Council of Election Committee. Meanwhile, the authorities of the Election Supervisory Board include; receiving and following up on reports relating to alleged violations in the implementation of legislation governing general election; examining, analyzing and deciding on violations in general election administration; examining, analyzing and deciding on violations of money politics; and receiving, examining, mediating or 
adjudicating, and deciding upon the resolution of election process disputes. Based on these authorities, the Election Supervisory Board as an institution is a super-body general election organizer in handling election violations [9].

In connection with this legal culture, according to Roger Cotterrell, the concept of legal culture explains the diversity of ideas about a law that exists in various societies and their position in the social order. These ideas explain legal practices, citizens' attitudes toward law and their willingness and unwillingness to file cases, and relative legal significance, in explaining broad thoughts and behaviors outside of practice and specific forms of discourse related to legal institutions. Thus, variations in legal culture may be able to explain much about the differences in ways in which legal institutions that appear to be the same can function in different societies [10].

\section{Conclusion}

Election criminal acts are regulated in Law Number 7 of 2017 Concerning General Elections, namely Article 488 to Article 554. Election criminal law enforcement in Indonesia there are 116 cases consisting of 29 cases of money politics, 22 cases of acts harming election participants, 15 cases of counterfeiting, 10 cases of campaigning in places of worship or educational institutions, 9 cases of campaigning out of schedule, 17 cases of campaigning involving banned parties, 7 cases of campaigning using government facilities, 5 cases of destruction of props and 2 cases regarding the election participants' marriages and about the list data general election, then in general implementation has run well even though at the level of implementation there are only weaknesses such weaknesses of the structure in this case there are still law enforcement officers in this case GAKUMDU namely bawaslu, police and prosecutors who experience weaknesses such as weaknesses in terms of the budget, human resources and as shutter and infrastructure in addition to that the culture of the community which is still low in election awareness in Indonesia makes violations of election crimes still high so it is necessary to increase public legal awareness through socialization, workshops, seminars, education and training on electoral regulations especially regarding election criminal acts to the public.

\section{Acknowledgement}

We thanks to Directorate General of Research and Innovation Indonesia, Universitas Kuningan and UGJ for funding this research.

\section{References}

[1] Hikam, Muhammad A.S. Politik Kewarganegaraan, Landasan Redemokratisasi di Indonesia, Penerbit Bentara, Jakarta, 2002.

[2] Bachtiar, Farahdiba Rahma, Pemilu Indonesia: Kiblat Negara Demokrasi Dari Berbagai Refresentasi, Jurnal Politik Profetik Volume 3 Nomor 1 Tahun 2014.

[3] Hiariej, Eddy O.S., Pemilukada Kini dan Masa Datang Perspektif Hukum Pidana dalam Demokrasi Lokal - Evaluasi Pemilukada di Indonesia, Jakarta: Konstitusi Press, 2012. 
[4] Handitya, Binov, Peran Sentra Penegakan Hukum Terpadu (Gakkumdu) dalam Penegakkan Tindak Pidana Pemilu, Seminar Nasional Hukum Universitas Negeri Semarang, Volume 4 Nomor 2 Tahun 2018, pp. 348-365

[5] Fahmi, Khairul, sistem penanganan tindak pidana pemilu, Jurnal Konstitusi, Volume 12, Nomor 2, Juni 2015

[6] Harun, Refly, Reconstruction of Authority in the Settlement of Dispute Over the Result of General Election, Jurnal Konstitusi, Volume 13, Nomor 1, Maret 2016

[7] Santoso, Topo, Tindak Pidana Pemilu Di Indonesia: Tinjauan Khusus Tentang Politik Uang, Makalah dalam seminar Mahupiki di Universitas Indonesia, 2018, pp.1-15

[8] Yuliyanti, Selvi, Pertanggungjawaban Pidana Terhadap Pelaku Tindak Pidana Pemilu Legislatif Tahun 2014 (Studi Putusan Nomor: 70/Pid./2014/Pt.Tjk), Fiat Justisia Journal of Law, Volume 10 No. 1, January-March 2016, pp.175-200

[9] Rahmat, Diding, Teguh Prasetyo and Sri Endah Wahyuningsih, Advocate Policy In Guidance For Accompaniment Child Case In Indonesia, Opción, Año 34, No. 85 ,2018, pp.1371-1380.

[10] Huda, Uu Nurul, The Position and Authority of the Election Supervisory Board in Indonesian Constitutional System, UNIFIKASI : Jurnal Ilmu Hukum, Volume 06 Nomor 01, 2019. 